\title{
Use of Percutaneous Sonographically Guided Microwave Ablation Therapy to Treat Inoperable Malignant Liver Tumours
}

\author{
QC Wang ${ }^{1}$, W Cheng ${ }^{1}$, L Zhang ${ }^{1}$, Y Sun ${ }^{1}$, YX Sun ${ }^{1}$, CH Xing ${ }^{2}$
}

\begin{abstract}
Aims: Microwave ablation (MWA) is a technique which is used to destroy tumours and soft tissues by using microwave energy to create coagulation and localized tissue necrosis. It is used to treat the tumours which are considered to be inoperable and used to treat those patients who are ineligible for surgery due to some factors. The main objective of this study was to evaluate the use of MWA in the treatment of liver cancer.

Methods: The data were collected from Department of Ultrasound, Harbin Medical University Cancer Hospital. From July 2010 to August 2011, a total of 123 patients with liver tumours was referred to Harbin Medical University Cancer Hospital. One hundred patients were selected for this study and treated with MWA. The study group contained $64(64 \%)$ males and $36(36 \%)$ females with an average age $( \pm S D)$ of $52( \pm 5.1)$ years.

Results: One month after therapy, complete ablation was obtained in nodules. The complete ablation rate in tumors $\leq 3 \mathrm{~cm}$ and those $>3 \mathrm{~cm}$ was $98 \%$ and $94 \%$, respectively. Microwave ablation success was higher with nodules $\leq 3 \mathrm{~cm}(57 / 58 ; 98.3 \%)$ in comparison to nodules $>3 \mathrm{~cm}$.

Conclusion: Sonographically guided percutaneous microwave ablation proved to be safe, fast and effective for treatment of hepatocellular carcinoma.
\end{abstract}

Keywords: Hepatocellular carcinoma, microwave ablation, percutaneous, treatment

\section{Uso de la Terapia de Ablación Percutánea con Microondas Guiada por Ecografía para el Tratamiento de Tumores de Hígado Malignos Inoperables}

\author{
QC Wang ${ }^{1}$, W Cheng ${ }^{1}$, L Zhang ${ }^{1}$, Y Sun ${ }^{1}$, YX Sun ${ }^{1}$, CH Xing ${ }^{2}$
}

\begin{abstract}
RESUMEN
Objetivos: La ablación con microondas (MWA) es una técnica que se utiliza para destruir tumores y tejidos blandos mediante el uso de la energía de microondas que producen coagulación y necrosis tisular localizada. Se utiliza para tratar los tumores considerados inoperables, así como para el tratamiento de pacientes no elegibles para cirugía debido a determinados factores. El objetivo principal de este estudio fue evaluar el uso de MWA en el tratamiento del cáncer de higado.

Métodos: Se recopilaron datos del Departamento de Ultrasonido del Hospital Oncológico de Harbin Medical University. De julio de 2010 a agosto de 2011, un total de 123 pacientes con tumores hepáticos fueron remitidos al Hospital Oncológico de Harbin Medical University. Cien pacientes fueron seleccionados para este estudio y tratados con MWA. El grupo de estudio estuvo formado por 64 varones $(64 \%)$ y $36(36 \%)$ mujeres con una edad promedio $( \pm S D)$ de $52( \pm 5.1)$ años.

Resultados: Un mes después de la terapia, la ablación completa se obtuvo en los nódulos. La tasa de ablación completa en tumores $\leq 3 \mathrm{~cm}$ y tumores $>3 \mathrm{~cm}$ fue de $98 \%$ y $94 \%$, respectivamente. El éxito de la ablación con microondas fue mayor con nódulos $\leq 3 \mathrm{~cm}(57 / 58 ; 98.3 \%)$ en comparación con nódulos $>3 \mathrm{~cm}$.

Conclusión: La ablación percutánea con microondas guiada mediante ecografía demostró ser segura, rápida y eficaz para el tratamiento del carcinoma hepatocelular.
\end{abstract}

From: ${ }^{1}$ Department of Ultrasound, Harbin Medical University Cancer Hospital, Heilongjiang province 150081 , China and ${ }^{2}$ Department of Anesthesiology, Harbin Medical University Cancer Hospital, Heilongjiang province 150081, China.
Correspondence: Dr W Cheng, Department of Ultrasound, Harbin Medical University Cancer Hospital, Heilongjiang province 150081, China. Fax: 0086451-86298227; e-mail:chengwen69@yahoo.com 
Palabras claves: Hepatocarcinoma, ablación por microondas, percutáneo, tratamiento

West Indian Med J 2015; 64 (2): 77

\section{INTRODUCTION}

Microwave ablation (MWA) is a technique which is used to destroy tumours and soft tissues by using microwave energy to create coagulation and localized tissue necrosis. It is used to treat the tumours which are considered to be inoperable and used to treat those patients who are ineligible for surgery due to some factors. Microwave ablation is performed as an open procedure eg laparoscopically, percutaneously under image guidance (ultrasound, computed tomography and magnetic resonance imaging) with sedation, or local or general anaesthesia (1).

Microwave ablation technique uses the microwave energy $(2.45 \mathrm{GHz})$ and alternating electric field which cause rotation and production of heat. In MWA, a single microwave antenna or multiple antennae connected to a generator are inserted into the affected area or at the point of tumour to be ablated. Energy from these antennae is generated and produces friction and heat. The heat coagulates with the tissue and produces a small area of ablation. If the tumour is greater than $2 \mathrm{~cm}$ in diameter then multiple antennae are used for ablation (2).

Liver cancer is the sixth most common cancer in the world (3). In males, it is the fifth most common cancer, while in females it ranks seventh (4). In spite of it being the sixth most common cancer worldwide, liver cancer is associated with more mortalities than many other cancers. This is evident from the fact that it is the third most common cause of cancer-related deaths worldwide in both genders (5). Lung cancer is by far the most common cancer in the world as well as the most common cause of cancer-related deaths, followed by stomach cancer as the second most common cause of cancer-related deaths in both genders of all ages (5).

According to the World Health Organization's subsidiary International Agency for Research on Cancer (IARC) reports, in the year 2008, 748000 new liver cancer cases were recorded, and it was responsible for 696000 deaths in the year 2008 alone (6). Around $85 \%$ of the total liver cancer cases occurs in less developed countries. It is also important to note that more than $50 \%$ of all liver cancer cases occur in China alone. These data point out the gravity of the situation and also the important variations in liver cancer incidence around the world (6). Hepatocellular carcinoma (HCC) is the major form of liver cancer that involves the primary functional cells of liver $i e$ hepatocytes. Hepatocellular carcinoma accounts for $85-90 \%$ of all liver cancer cases (7). Multiple aetiological factors are responsible for HCC. Infection with the two most dangerous hepatitis viruses, namely hepatitis B virus (HBV) and hepatitis $\mathrm{C}$ virus $(\mathrm{HCV})$, has been recorded as the underlying aetiology in more than three-fourths $(78 \%)$ of total HCC cases (6). Other important factors which are responsible for HCC include exposure to fungal toxin (aflatoxin), hemochromatosis, chronic alcoholism and anabolic steroids. All these factors combined account for only $22 \%$ of total HCC cases $(6,8)$.

Hepatitis B virus is the most common cause of HCC and accounts for around $53 \%$ of total $\mathrm{HCC}$ cases alone worldwide. However, contrary to worldwide trend, HCV is a more common aetiology underlying HCC in certain areas of high HCV prevalence. These areas include Japan, Pakistan and Egypt. Moreover, with the introduction of a vaccine against HBV and the availability of effective therapeutic options, incidence of $\mathrm{HBV}$ infection is expected to decline markedly in the coming years. However, no vaccine is available as yet for $\mathrm{HCV}$ and the therapies available have been found to be less effective. Therefore it is expected that in coming years, $\mathrm{HCV}$ will take over as the most common cause of HCC worldwide (9).

The main objective of this study is to evaluate the use of MWA in the treatment of liver cancer.

\section{SUBJECTS AND METHODS}

The study was conducted in accordance with the principles of medical research ethics set forth by the Declaration of Helsinki (2008), a set of ethical principles promulgated by the World Medical Association (WMA). All patients included in the study provided an informed consent and the patients' details were kept anonymous except for the two persons directly involved in data accumulation. As per WMA principles, the patients were duly assigned code numbers and any further analysis of patient data used the assigned code numbers instead of original name or any other identifications.

The data were collected from Department of Ultrasound, Harbin Medical University Cancer Hospital. From July 2010 to August 2011, a total of 123 patients with liver tumours was referred to Harbin Medical University Cancer Hospital. One hundred patients were selected for this study and treated with MWA. The study group contained 64 (64\%) males and 36 $(36 \%)$ females with an average age $( \pm \mathrm{SD})$ of $52( \pm 5.1)$ years. Exclusion criteria were on the basis of the following points: age older than 70 years, more than five intrahepatic nodules and presence of extrahepatic metastasis.

Liver function tests were performed for the evaluation of liver efficiency. For this purpose, alanine aminotransferase (ALT), aspartate aminotransferase (AST), alkaline phosphatase (ALP), serum albumin and alpha-fetoprotein were performed. Computed tomography (CT) was also performed for the evaluation of liver efficacy. The number of patients with single tumour nodule was $84(63.9 \%)$ and those with two tumour nodules were $16(36.1 \%)$. A total of 88 tumour nodules sized $2-5 \mathrm{~cm}$ with an average diameter $( \pm \mathrm{SD})$ of $4.2( \pm 0.9)$ was treated. Serum creatinine and complete blood profile were also used for the evaluation purpose.

Microwave ablation was performed percutaneously under real time ultrasound guidance using a BSD Medical Cor- 
poration's MicroThermX Microwave Ablation System (MTX180 ) with a $3.5-5 \mathrm{MHz}$ probe. The ablation procedure was done by using general anaesthesia. This microwave delivery system consists of a generator, an output power and electrodes to deliver microwave energy to the liver tissues. The skin was prepared for ablation. A guide needle with a sheath was inserted and positioned at the designated place of the tumour under sonographic guidance then the guide needle was pulled out. The tip of the electrode was placed at the bottom of the lesion about $0.4-0.6 \mathrm{~cm}$ inside the tumour margin after which it was connected to the generator and the energy application was started. If the tumour was $<3 \mathrm{~cm}$, then we stopped the treatment at this point, otherwise, the direction was changed and the needle moved backward. The procedure was performed two to three times according to the size of the tumours.

\section{RESULTS}

The study included all the cases from July 2010 to August 2011, 100 patients with liver tumours that fulfilled the inclusion criteria. The study group contained 64 (64\%) males and $36(36 \%)$ females with an average age ( \pm S.D) of 52 years $( \pm 5.1)$. All the patients completed the MWA procedure carefully and average time for ablation was 10 minutes. The technical success rate for the tumour was very high (Fig. 1).

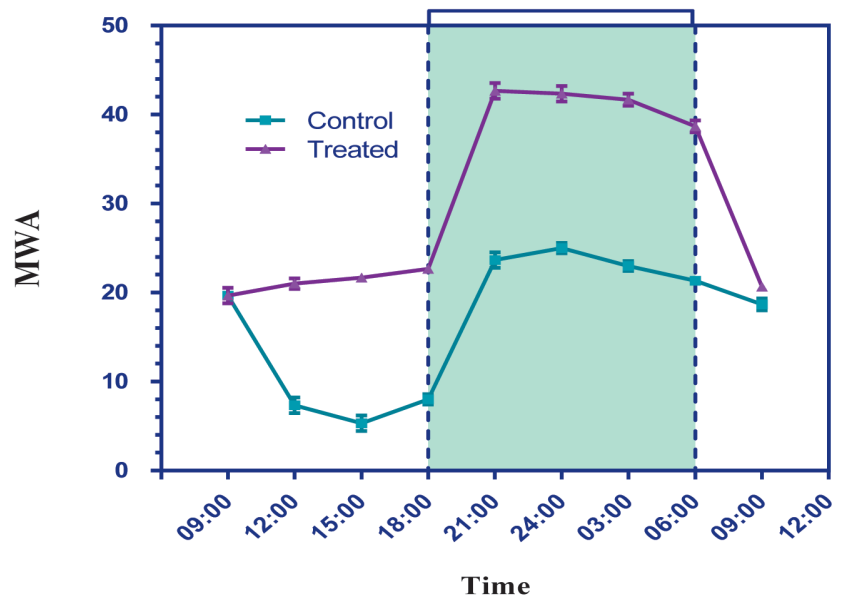

Fig. 1: The above graph shows the level of liver efficiency before and after treating with microwave ablation (MVA). Liver efficiency increases after the treatment of MWA.

Microwave ablation success rate was high in the tumour size less than $3 \mathrm{~cm}$ as compared to the tumour greater than $3 \mathrm{~cm}$. The demographic characteristics were also calculated before the treatment of microwave ablation (Table 1). A demographic characteristic shows that there is a high level of liver enzymes after MWA (Table 2). During this limited period, none of the patients died and no new lesions were detected.

Alpha-fetoprotein was considered to be a very important factor of liver efficacy. So, it was measured at every point (Fig. 2). Comparison between preoperative versus the postoperative
Table 1: Demographic and clinical parameters of patients before microwave ablation

\begin{tabular}{lcc}
\hline Gender & Male & $64(64 \%)$ \\
& Female & $36(36 \%)$ \\
Age (years) & Male & $57.0 \pm 4.6$ \\
& Female & $59.0 \pm 2.3$ \\
Encephalopathy & None & $100 \%$ \\
Albumin (g/dL) & - & $3.2 \pm 0.5$ \\
Bilirubin (g/dL) & - & $1.8 \pm 1.5$ \\
ALT (U/L) & - & $55.9 \pm 20.5$ \\
AST (U/L) & - & $49.0 \pm 19.6$ \\
ALP (U/L) & - & $105.0 \pm 19.4$ \\
TP (g/dL) & - & $13.3 \pm 1.5$ \\
Hb (g/dL) & - & $11.4 \pm 1.5$ \\
Creatinine (mg/dL) & - & $0.9 \pm 0.4$ \\
Blood sugar (mg/dL) & - & $112.3 \pm 0.4$ \\
\hline
\end{tabular}

ALT - alanine aminotransferase; AST - aspartate aminotransferase; ALP - alkaline phosphatase; $\mathrm{TP}$ - total protein; $\mathrm{Hb}$ - haemoglobin

Table 2: Clinical parameters of patients after microwave ablation

\begin{tabular}{lcc}
\hline Encephalopathy & None & $100 \%$ \\
Albumin (g/dL) & - & $4.2 \pm 0.9$ \\
Bilirubin (g/dL) & - & $3.9 \pm 1.5$ \\
ALT (U/L) & - & $87.8 \pm 20.5$ \\
AST (U/L) & - & $55.9 \pm 19.6$ \\
ALP (U/L) & - & $120.1 \pm 19.4$ \\
TP (g/dL) & - & $23.3 \pm 1.5$ \\
Hb (g/dL) & - & $9.8 \pm 1.5$ \\
Creatinine (mg/dL) & - & $1.2 \pm 0.4$ \\
Blood sugar (mg/dL) & - & $112.3 \pm 0.4$ \\
\hline
\end{tabular}

ALT - alanine aminotransferase; AST - aspartate aminotransferase; $\mathrm{ALP}$ - alkaline phosphatase; $\mathrm{TP}$ - total protein; $\mathrm{Hb}$ - haemoglobin

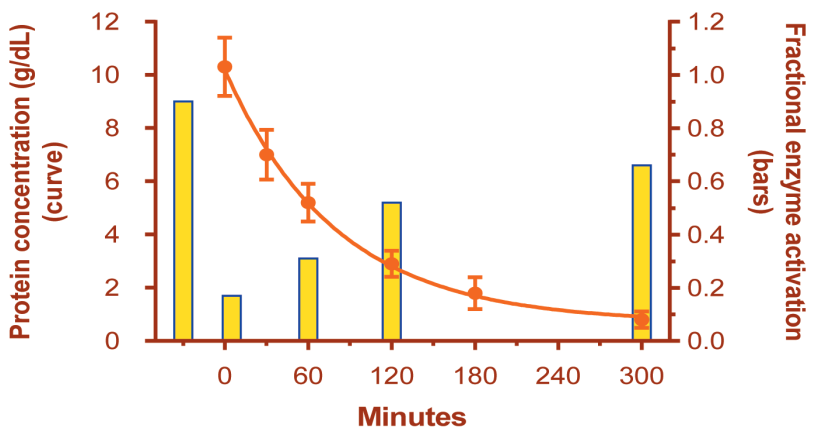

Fig. 2: Concentration of alpha-fetotoprotein before and after treatment of microwave ablation (MWA). Level of alpha-fetotoprotein decreases with respect to time and treatment. The decreasing line of graph shows the level of protein.

alpha-fetoprotein values showed that values significantly declined with time.

The contrast-enhanced transverse CT scans were shown with two HCC nodules (Fig. 3). Pretreatment scan revealed a $1.3 \mathrm{~cm} \mathrm{HCC}$ and $2.2 \mathrm{~cm} \mathrm{HCC} \mathrm{(Fig.} \mathrm{3A).} \mathrm{The} \mathrm{scan} \mathrm{obtained}$ one month after percutaneous microwave coagulation therapy (PMCT) depicted a non-enhancing hypo-attenuating area at previously mentioned sites of tumour nodules (Fig. 3B). Pre- 

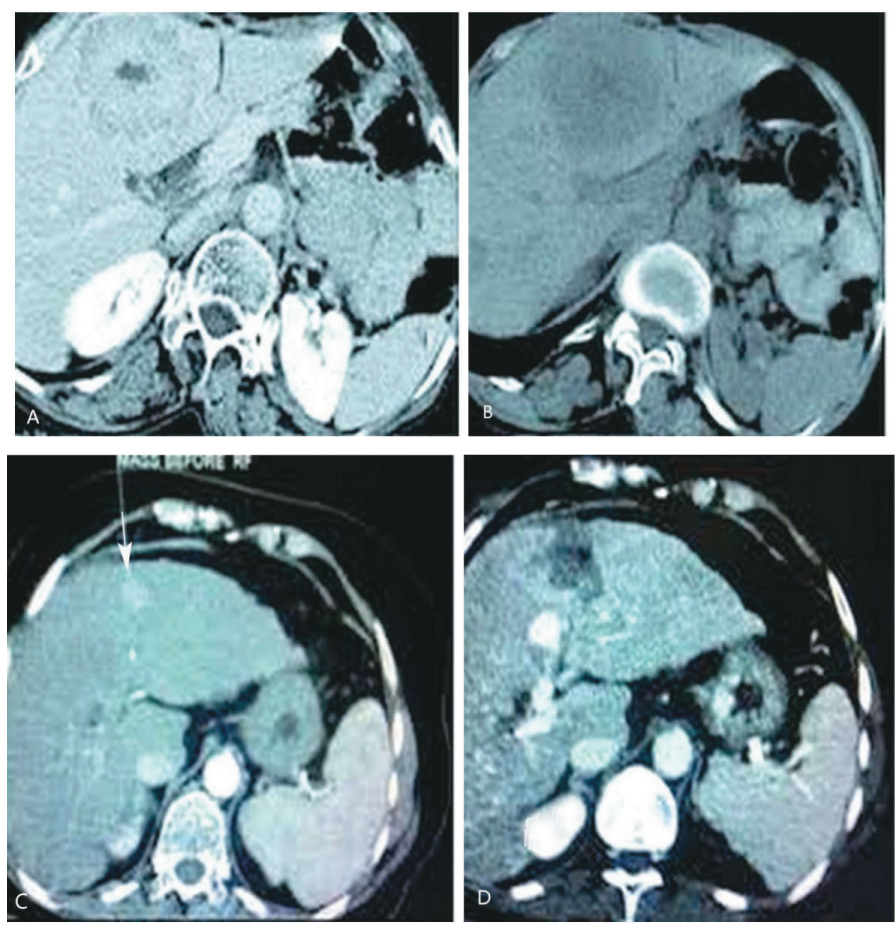

Fig. 3: Contrast-enhanced transverse computed tomography (CT) scan with two hepatocellular carcinoma (HCC) nodules. (A) Pretreatment scan reveals a $1.3 \mathrm{~cm} \mathrm{HCC}$ and $2.2 \mathrm{~cm} \mathrm{HCC}$. (B) Scan obtained one month after percutaneous microwave coagulation therapy (PMCT) depicts non-enhancing hypoattenuating areas at previously mentioned sites of tumour nodules. (C) Pretreatment contrast enhanced image depicts a $4.5 \mathrm{~cm}$ enhancing nodule (arrow). (D) Contrast enhanced scan three months after PMCT shows a non-enhancing hypoattenuating area.

treatment contrast-enhanced image depicted a $4.5 \mathrm{~cm}$ enhancing area [arrow] (Fig. 3C). Contrast-enhanced scan three months after PMCT showed a non-enhancing hypo-attenuating area (Fig. 3D).

The contrast-enhanced transverse CT scans with solitary HCC was also shown (Fig. 4). Pretreatment contrast enhanced scan revealed a $3.5 \mathrm{~cm}$ enhancing HCC (Fig. 4 A). Scan obtained one month after PMCT depicted a non-enhancing hypoattenuating area with evident safety margin (Fig. 4B).
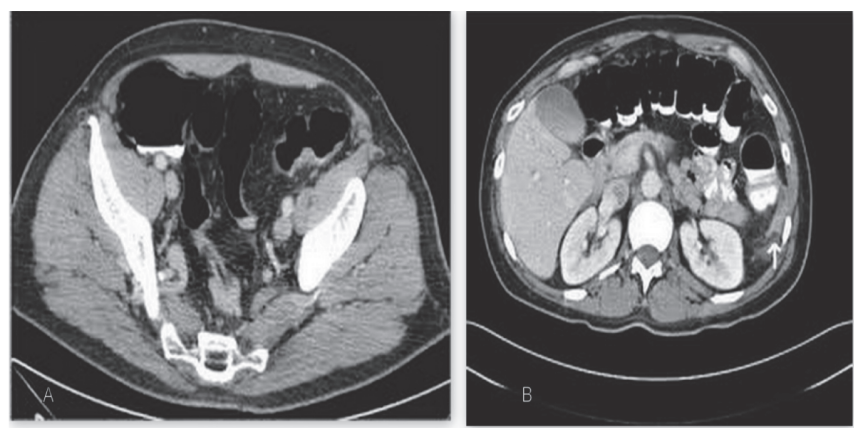

Fig. 4: Contrast-enhanced transverse computed tomography (CT) scans with solitary hepatocellular carcinoma (HCC). (A) Pretreatment contrastenhanced scan reveals a $3.5 \mathrm{~cm}$ enhancing HCC. (B) Scan obtained one month after percutaneous microwave coagulation therapy depicts a non-enhancing hypo-attenuating area with evident safety margin.
In our study, no complication occurred related to the ablation procedure. Forty-eight patients had a moderate fever, which lasted one to two days. In two patients, a small discharge from the puncture wound occurred in the initial days after therapy. No other clinically relevant complications were observed.

\section{DISCUSSION}

Microwave thermal ablation is considered to be the most powerful tool for the treatment and management of HCC (10). In recent years, the potential role of microwave ablation has become increasingly apparent; microwave device and antenna have been greatly improved (11). In this study, a $2450 \mathrm{MHz}$ internally cooled-shaft antenna was used (12).

This study reports the first initial utilization of this type of microwave technology in the management of HCC at our institution. Microwave ablation appeared to be a well-tolerated treatment in our patients. Cell-free DNA in the serum/ plasma is believed to originate from the dead cells. In a cancerous patient, quantity of cell-free DNA is markedly increased due to increased turnover of cellular division and death. This fact has been exploited for clinical diagnosis of a variety of cancers. This circulating cell-free DNA can also be used for promoter methylation profiling of tumour tissue as many studies have suggested a concordance of DNA methylation profiles between the tumorous tissue and the circulating cellfree DNA from a single patient (13). Our results confirm the utility of cell-free DNA for epigenetic profiling as we found a high level of concordance between the methylation levels in tissue samples and cell-free DNA in all the genes. The concordance ranged between 70 and $90 \%$.

To our knowledge, there are only a handful of studies which have investigated the link between promoter hypermethylation and prediction of response to therapy. In a study by Hamilton et al, it was found that the number of genes methylated in responder patients was considerably lower than those in patients who responded well to the therapy (14).

The limitation of our study is that it was a short-term preliminary study.

\section{AUTHORS' NOTE}

All the authors contributed equally. The guarantor of integrity of the entire study is Qiucheng Wang. The study concept is designed by Qiucheng Wang and Wen Cheng, and definition of intellectual content is from Wen Cheng and Lei Zhang. The literature research is by Qiucheng Wang, Lei Zhang and Yixin Sun.

\section{REFERENCES}

1. Zhou W, Zha X, Liu X Ding Q, Chen L, Ni Y et al. US-guided percutaneous microwave coagulation of small breast cancers: a clinical study. Radiology 2012; 263: 364-73.

2. Ong SL, Gravante G, Metcalfe MS, Strickland AD, Dennison AR, Lloyd DM. Efficacy and safety of microwave ablation for primary and secondary liver malignancies: a systematic review. Eur J Gastroenterol Hepatol 2009; 21: 599-605. 
3. Bray F, Ren JS, Masuyer E, Ferlay J. Global estimates of cancer prevalence for 27 sites in the adult population in 2008. Int J Cancer 2013; 132: 1133-45.

4. Soerjomataram I, Lortet-Tieulent J, Parkin DM, Ferlay J, Mathers C, Forman D et al. Global burden of cancer in 2008: a systematic analysis of disability-adjusted life-years in 12 world regions. Lancet 2012; 380: $1840-50$.

5. Ferlay J, Shin HR, Bray F, Forman D, Mathers C, Parkin D. Estimates of worldwide burden of cancer in 2008: GLOBOCAN 2008. Intl J Cancer 2010; 127: 2893-917.

6. Jemal A, Center M, DeSantis C, Ward E. Global patterns of cancer incidence and mortality rates and trends. Cancer Epidemiol Biomarkers Prev 2010; 19: 1893-907.

7. Farazi PA, DePinho RA. Hepatocellular carcinoma pathogenesis: from genes to environment. Nat Rev Cancer 2006; 6: 674-87.

8. Ferenci P, Fried M, Labrecque D, Bruix J, Sherman M, Omata M et al. Hepatocellular carcinoma (HCC): a global perspective. J Clin Gastroenterol 2010; 44: 239-45.
9. Kew MC. Synergistic interaction between aflatoxin B1 and hepatitis B virus in hepatocarcinogenesis. Liver Int 2003; 23: 405-9.

10. Lau WY, Leung TWT, Yu SCH, Ho SKW. Percutaneous local ablative therapy for hepatocellular carcinoma. A review and look into the future. Am Surg 2003; 237: 171-9.

11. Hines-Peralta AU, Pirani N, Clegg P, Cronin N, Ryan TP, Liu Z et al. Microwave ablation: results with a $2.45-\mathrm{GH}$ applicator in ex vivo bovine and in vivo porcine liver. Radiology 2006; 239: 94-102. Epub 2006 Feb 16.

12. Shi W, Liang P, Zhu Q, Yu X, Shao Q, Lu T et al. Microwave ablation: results with double $915 \mathrm{MHz}$ antennae in ex bovine livers. Eur J Radiol 2011; 79: 214-7. doi: 10.1016/j.ejrad.2010.03.015. Epub 2010 Apr 14.

13. Sharma G, Mirza S, Parshad R, Gupta S, Ralhan R. DNA methylation of circulating DNA: a marker for monitoring efficacy of neoadjuvant chemotherapy in breast cancer patients. Tumour Biol 2012; 33: 1837-43.

14. Hamilton J, Sato F, Greenwald B, Suntharalingam M, Krasna M, Edelman $\mathrm{M}$ et al. Promoter methylation and response to chemotherapy and radiation in esophageal cancer. Clin Gastroenterol Hepatol 2006; 4: 701-8. 